\title{
Village cadre behavior in the household-based management of inorganic waste
}

\section{Perilaku kader desa dalam pengelolaan sampah anorganik berbasis rumah tangga}

\author{
Agnes Fitria Widiyanto*, Arif Kurniawan, \& Elviera Gamelia \\ Department of Public Health, Faculty of Health Sciences, Universitas Jenderal Soedirman \\ Address: J1. DR. Soeparno No.61, Karang Bawang, Purwokerto, Central Java, 53111 \\ E-mail: afitriawidiyanto@yahoo.com
}

Article History: Received 3 February 2020; Accepted 16 June 2021; Published Online 24 June 2021

\begin{abstract}
Waste is still a problem in Indonesia. The increase in population causes the volume of waste to continue to grow, in Karangmangu Village, Banyumas Regency. Data on the increase in the volume of waste in Banyumas Regency reached $21.4 \%$. The volume of inorganic waste is greater than organic waste because Karangmangu Village is a tourism buffer area in Baturraden. This study aimed to describe the knowledge, attitudes, and practices of cadres in the management of inorganic waste. The method used was descriptive qualitative. The research subjects were obtained using a purposive technique by conducting interviews with cadres as the main research subjects, midwives, and supporting informants. Data were collected through in-depth interviews and documentation. The results showed that the cadres had understood the definition, types, management, and negative impacts of inorganic waste. Based on their attitudes, the cadres consider the case of handling inorganic waste to be not optimal. In practice, they have sorted inorganic waste, managed a waste bank, made bricks, and produced handicrafts. Strategies to overcome obstacles in waste management are optimizing the facilities and infrastructure for the procurement of waste banks, as well as training more people to make handicrafts and market handicraft products. This study concludes that the presence of village cadres is able to increase public awareness in waste management.
\end{abstract}

Keywords: inorganic waste; waste management; village cadre

\begin{abstract}
Abstrak
Sampah masih menjadi masalah di Indonesia. Pertambahan jumlah penduduk membuat volume sampah terus meningkat, termasuk di Desa Karangmangu, Kabupaten Banyumas. Data volume kenaikan sampah di Kabupaten Banyumas mencapai 21,4\%. Volume sampah anorganik lebih besar daripada sampah organik karena Desa Karangmangu merupakan daerah penyangga wisata di Baturraden. Tujuan penelitian ini adalah mendeskripsikan pengetahuan, sikap, dan praktik kader dalam pengelolaan sampah anorganik. Metode yang digunakan adalah kualitatif deskriptif. Subjek penelitian diperoleh dengan menggunakan teknik purposive dengan melakukan wawancara kepada kader sebagai subjek penelitian utama, bidan, dan informan pendukung. Data dikumpulkan melalui wawancara mendalam dan dokumentasi. Hasil penelitian menunjukkan bahwa kader sudah memahami pengertian, jenis, pengelolaan, dan dampak negatif sampah anorganik. Berdasarkan sikapnya, kader menganggap kasus penanganan sampah anorganik belum maksimal. Pada praktiknya, kader sudah memilah sampah anorganik, mengelola bank sampah, membuat batako, serta membuat kerajinan tangan. Strategi untuk mengatasi kendala dalam pengelolaan sampah yaitu mengoptimalkan sarana dan prasarana pengadaan bank sampah, serta melatih lebih banyak masyarakat untuk membuat kerajinan dan memasarkan produk kerajinan. Studi ini menyimpulkan bahwa keberadaan kader desa mampu meningkatkan kesadaran masyarakat dalam pengelolaan sampah.
\end{abstract}

Kata kunci: sampah anorganik; pengelolaan sampah; kader desa

\section{Introduction}

Waste is a problem in Indonesia. The increase in population makes the volume of waste continue to grow, including in Karangmangu Village. The volume of inorganic waste is greater than organic waste because it is unbiodegradable and can cause environmental pollution. Inorganic waste has a negative impact on health and the environment if it is not managed properly (Budiasih 2010). It can be a breeding ground for pathogens and disease vectors. In addition to making the surrounding environment slum and dirty, it can clog drainage channels which result in flooding (Jimung 2008). As a buffer zone for 
tourism objects, environmental cleanliness in Karangmangu Village is one of the keys to the success of tourist attractions because tourists prefer comfortable environmental conditions. This supports the local economy.

Inorganic waste takes longer to decompose than organic waste. Inorganic waste is produced from materials in the form of synthetic products or the result of technological processes for the management of mining materials or natural resources that cannot be decomposed by nature (Christiawan \& Citra 2016). Regarding the obstacles faced by the community in waste management, 33\% of them stated that they had not received a waste pick-up service to their homes and $23 \%$ of them stated that they did not have a Waste Disposal Site (TPS) in their neighborhood association (RT). In addition to these obstacles, it was also revealed that waste pick-up service is sometimes not carried out every day. Besides the insufficient number of trash cans, some people also do not know how to process waste. Meanwhile, the obstacles faced by the government are 1) the lack of facilities such as TPS, 2) the unavailability of a waste pick-up fleet in all regions, 3) the lack of 3R experts (Rahman 2013). 87.3\% of respondents indicated that knowledge about waste management was in the medium category, $83.1 \%$ of respondents indicated attitudes in waste management were in the medium category, and $87.3 \%$ of respondents indicated that actions in waste management were in the poor category. Improving waste management behavior can be done by providing counseling to housewives about proper waste management so that they can better understand and apply the waste management methods (Fitriana \& Oedojo 2013; Chotimah 2015).

Waste can be beneficial to the environment (Tampubolon et al. 2014). Environmental cleanliness is generated by proper management of inorganic waste with the $3 \mathrm{R}$ principles, which are reduce, reuse, and recycle (Kabupaten Banyumas 2010; Susilowati \& Herdiansyah 2019). Human behavior in waste management which is part of health behavior is all individual's observable or unobservable activities related to the maintenance and improvement of health (Notoatmodjo 2010). Community behavior in managing inorganic waste is also affected by internal factors, which is awareness within themselves to manage inorganic waste (Chen \& Gao 2020; Lissah et al. 2021; Pierini et al. 2021) and external factors including the availability of facilities and infrastructure as well as support from related parties in managing inorganic waste (Hamudy \& Mujaeni 2021).

Health cadres can become Agents of Change as intermediaries for community empowerment, particularly in terms of the management of inorganic waste. They can mobilize the community to participate in maintaining environmental sanitation because they can become role models of the community that influence people's behavior, especially in terms of the management of inorganic waste. Inorganic waste management can run smoothly when the cadres as community movers participate. Therefore, the community also participates in managing inorganic waste. Proper knowledge about environmental care behavior is the primary component of internal factors that can encourage changes in a person's attitude to be more concerned about the environment (Beni et al. 2014). The factors influencing behavior in the management of inorganic waste are significantly influenced by knowledge of community behavior although there is a lack of government socialization to the public regarding knowledge about waste (Beni et al. 2014; Meng et al. 2019; Liu et al. 2019).

The behavior of cadres applied in the field includes aspects of knowledge, attitudes, and practices in the management of inorganic waste. There are 34 health cadres in Karangmangu Village, but not all of them participate in the management of inorganic waste actively. Karangmangu Village is located in Baturraden District, Banyumas Regency, Central Java Province. The uniqueness of this area is shown by the environmental conditions where many residents have large lands, many rivers flow in the area, and the verdant conditions of the area. Accordingly, the challenge for people to keep disposing of waste in its place requires support for strengthening. Therefore, the researchers intended to look at the behavior of the cadres in household-based inorganic waste management in Karangmangu Village so that cadres are expected to be able to mobilize the Karangmangu Village community to participate in the management of inorganic waste. 


\section{Research Method}

The research method used was qualitative with a descriptive design. Research informants were determined by the purposive technique. The research informants were eight Karangmangu Village cadres consisting of five cadres as the main research subjects and three supporting research subjects including the Karangmangu Village Midwives, the head of the Village Health Forum (FKD), and the Final Disposal Site Manager (TPA).

Data was collected through interviews, literature studies, and documentation on aspects of knowledge, attitudes, and practices of cadres in the management of inorganic waste. The analysis was carried out using interactive analysis. The collected data was reduced to the main research findings that are relevant to the writing material and then presented narratively. Data reduction and presentation are two components of the analysis done simultaneously with the data collection process. The next process is drawing conclusions, which are carried out after the process of data collection, presentation, and description, then given meaning and logical interpretation.

\section{Results and Discussion}

\section{Cadre behavior and ways to increase public awareness in waste management}

The behavior carried out by cadres in the management of inorganic waste that is crucial to apply in Karangmangu Village includes practices of management of inorganic waste, the ways to manage inorganic waste, participation in inorganic waste management in Karangmangu Village, the ways to mobilize fellow cadres in managing inorganic waste, and the ways to invite the community to participate in the management of inorganic waste.

Based on in-depth interviews with the cadres, it was found that the behavior of informants in the management of inorganic waste includes managing a waste bank, sorting waste that can be deposited into the waste bank, sorting wet and dry waste, sorting clean and dirty waste, making handicrafts, making bricks from styrofoam, and utilizing mineral water bottles for soap dishes and piggy banks. This is depicted in figure 1 .

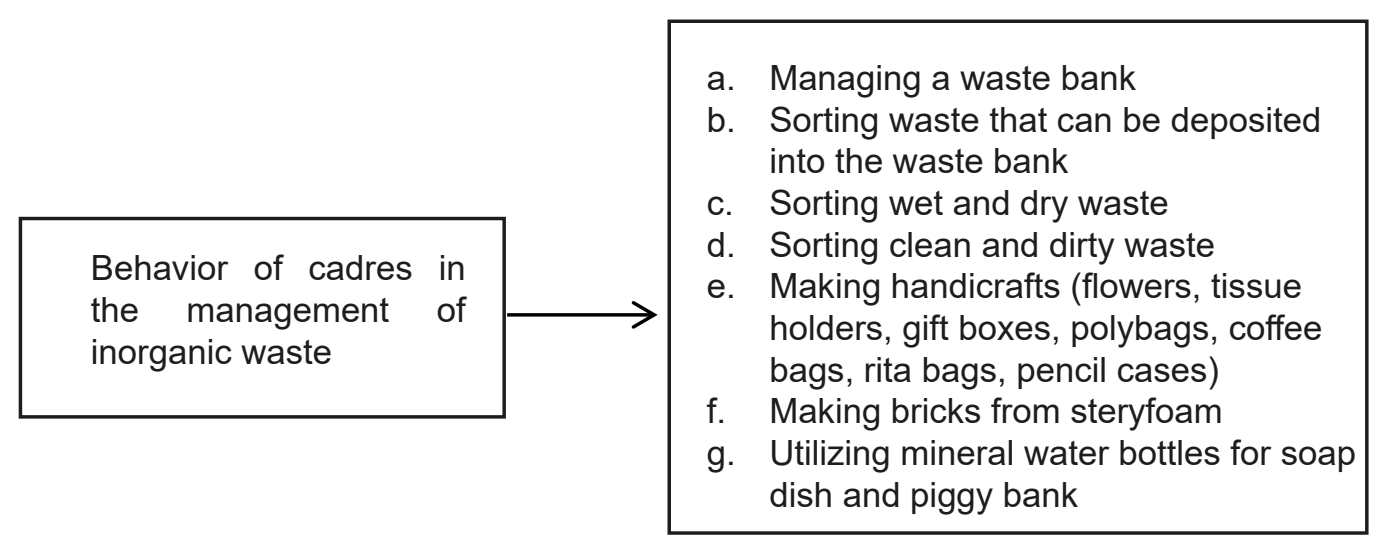

Figure 1.

The behavior of Cadres in the Management of Inorganic Waste Source: Processed primary data

The behavior of cadres in the management of the waste bank includes sorting waste of plastic, paper, glass, cloth, and other waste that can still be sold. Besides, the cadres also weigh the waste, record each customer who deposits inorganic waste and share the income at the end of the year to the customer. 
The management of inorganic waste performed by cadres by utilizing inorganic waste includes making various handicrafts such as flowers, tissue boxes, gift boxes, polybags, coffee bags, RITA bags, and pencil cases. Besides, one cadre makes bricks using styrofoam. These crafts are made by the cadres to fill spare time and to decorate their house. Only a small number of cadres sell them to increase their income. The principle of reuse is also performed by the cadres by utilizing plastic bottles as soap dishes and piggy banks.

The statement of the cadres in the management of inorganic waste was confirmed by the supporting informant of the village midwife who stated that the number of cadres who were active in the management of inorganic waste in Karangmangu Village was less than 10 people, as shown by the following quote:

“...regarding inorganic waste, they are used to making such bags and flowers. Then, they can also increase family income from the inorganic waste. The waste is also put into the waste bank" (SAR)

Health cadres should implement proper waste management and provide an example to the community on how to manage the waste properly. Environmental cadres are responsible to invite their neighbors to maintain the quality of the environment surrounding their homes, particularly those related to cleanliness and waste recycling. Environmental cadres are also obliged to provide their knowledge and skills of waste management to the community (Darwati \& Anggraini 2012).

Based on in-depth interviews with the cadres, it was found that the participation of cadres in the management of inorganic waste in Karangmangu Village includes managing the waste bank, depositing inorganic waste to waste banks regularly, providing training in making crafts for the women, and providing socialization to the community on the importance of the management of inorganic waste. This is illustrated in figure 2 .

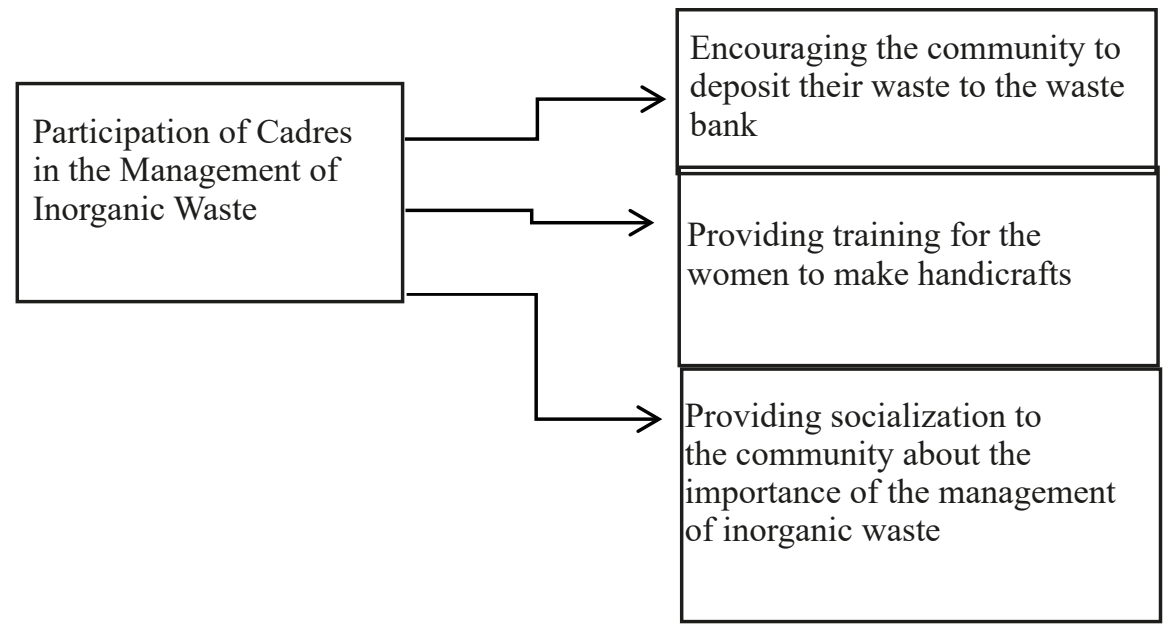

Figure 2.

Participation of Cadres in the Management of Inorganic Waste Source: Processed primary data

Cadres always encourage the community to be persistent in depositing inorganic waste once a week to the waste bank. Once a month at Neighborhood Association/Citizens Association (RT/RW), social gathering, or dasawisma meetings, most of the cadres also conduct socialization to the community about the importance of managing inorganic waste by encouraging them to deposit inorganic waste into the waste bank and training the women to make handicrafts. The handicrafts are made by using plastics, cardboards, and coffee wrappers that are no longer be used, for example, plastic bags are used to make flowers, cardboards are used to make gift boxes and tissue holders, and coffee wrappers are used to make bags. 
The cadres' statements that they participated in the management of inorganic waste in Karangmangu Village were confirmed by the supporting informants of the TPA manager and the head of the FKD that the cadres manage inorganic waste by making handicrafts such as flowers and managing the waste bank. This is evidenced in the following quote, "They make flowers, Ms. Sometimes I help find stems from the bonsai by buying them there (while pointing to the place to buy bonsai for flower crafts from made from plastic bags)" (DAR).

Cadres also play a role in providing socialization to the community regarding the importance of managing inorganic waste. It is in accordance with the role of cadres based on the Regulation of the Minister of Home Affairs Number 7 of 2007 concerning Cadres for Community Empowerment which states that the role of cadres as educators is to provide various positive and direct inputs as part of their experiences actively.

Based on in-depth interviews with the cadres, it was found that some of them mobilized fellow cadres in managing inorganic waste by holding discussions during routine meetings at the village hall, RT and RW meetings, or during socialization from the Community Health Centers (Puskesmas) to Karangmangu Village cadres. This socialization is held by the cadres once a month at the village hall discussing the development of the management of inorganic waste in Karangmangu Village, for example, the development of the use of the waste bank and the making of handicrafts from inorganic waste made by the cadres and the people of Karangmangu Village. Then, the cadres who attend regular meetings at the village hall convey information from the results of the socialization to the community at meetings in RT/ $\mathrm{RW}$, social gatherings, and dasawisma. This is evidenced in the following quote:

“...I conveyed what the wife of the Village Head said on the $9^{\text {th }}$ to the administrators of the Family Welfare Programs of the Neighborhood Association (PKK RT). This includes issues of waste management, environmental conditions. It's the responsibility of each one to clean the environment individually. If I convey it to the RT meeting on the $9^{\text {th }}$, later the wife of the head of RT will convey it to the community when there is an RT meeting, so it will be passed down, Ms" (YAN)

“...The cadres usually invite the community to participate in the waste bank program. The PKK has not yet been able to issue an appeal. However, we do data collection and socialization. There is a collaboration with the Community Health Centers indeed. At that moment, we provide socialization" (LIL)

The cadres' statement that they mobilized fellow cadres to manage inorganic waste was confirmed by the supporting informant of the village midwife, who stated that the cadres mobilized fellow cadres to manage inorganic waste in Karangmangu Village by conducting socialization every meeting of cadres or RT. This is evidenced in the following quote:

"Usually there is an RT meeting every month. Usually, the cadres bring their handicrafts such as flower vases, bags, or wallets. Then, they practice how to make the handicrafts and what materials are needed" (SAR)

Based on in-depth interviews with the cadres, it was found that some of them encouraged the community to participate in the management of inorganic waste by providing counseling once a month during RT/ RW meetings, social gatherings, and meetings at the village hall. In the socialization provided, the cadres discussed the problem of inorganic waste in Karangmangu Village, the utilization of inorganic waste, the use of waste banks, and the development of village waste banks. Usually, the cadres bring handicraft products from inorganic waste and practice how to make them in front of the community. Some cadres also encourage the community to manage inorganic waste every time they meet people on the street because they do not have time to disseminate information to the community in a formal meeting. This is evidenced in the following quote: 


\begin{abstract}
"In every social gathering, I always invite them to do it. When it comes to the invitation to create a waste bank, not everyone is aware of it. God willing, RT 7 has joined the waste bank because all the RT members here are committed, Ms. Whereas in RW, maybe only the wives of the heads of RW and RT administrators who are committed" (NAN)

"I do socialization at the village level. The Village Head also wants to issue a Village Regulation on PHBS. So far it's just a wish. If possible, PHBS, environmental cleanliness, and waste management are regulated in village regulations for the community. That's what we want. So far, only circulars and appeals are available" (LIL)
\end{abstract}

The cadre's statement about inviting the community to participate in the management of inorganic waste was justified by the supporting informant who stated that the cadre invited the community to make handicrafts from inorganic waste during routine meetings. This is as expressed in the following quote: "...yes, they invite us to make handicrafts when there is a meeting, Miss" (DAR).

Socialization activities are related to efforts to improve public knowledge and understand waste management, constraints, and obstacles as well as potentials that can be developed to improve community welfare. The socialization activity also aims to gain public support in general about the importance of sustainable waste management (Dwiyanto 2011; Rachman et al. 2020).

\title{
Supporting factors in the management of inorganic waste
}

Supporting factors consist of parties who participate in supporting the cadres in managing inorganic waste in Karangmangu Village. Based on in-depth interviews with the cadres, it was found that the parties and the roles of several parties supporting the management of inorganic waste in Karangmangu Village include the village government, the Urban Poverty Program (P2KP), UNSOED, Poltekes, village midwives, head of the Village Health Forum (FKD), Final Disposal Site Manager (TPA) managers, waste bank managers, the village head, health cadres, PKK groups, and Non-Governmental Organizations (NGOs).

While the forms of participation are in the form of providing garbage carts, garbage trucks, land for TPA, waste bank buildings, socialization, and handicraft competitions from inorganic waste, organic and inorganic waste bins, briefings, comparative studies, transportation of village waste, waste bank management, socialization, and empowerment to the community to manage inorganic waste. The parties who have participated in supporting the management of inorganic waste in Karangmangu Village for the past few years include the village government, village midwives, head of FKD, and Final Disposal Site Manager (TPA) managers. While the forms of participation include waste bank buildings, garbage carts, Final Disposal Sites (TPA), and training of management of inorganic waste in Yogyakarta. This is presented in table 1.

The statement of the supporting informant, the head of the FKD, is similar to the cadre that the parties participating in the management of inorganic waste are the waste bank controller and the TPA controller as mentioned in the following quote:

“...Two people handle waste bank management, including the perpetrator and the seller. Mr. Darwono was facilitated with a car by the village head to pick up trash. I also invite the community to visit Jogja just to refresh about the way to handle the waste" (NAH)

The success of the Community-Based Waste Management (PSBM) activities cannot be separated from good cooperation among various stakeholders, including the local government, cleaning agencies, research institutions, NGOs, foreign institutions, and local residents (Darwati \& Anggraini 2012; Naditya et al. 2012; Ferdiansyah \& Arsiyah 2014; Nurkomalasari 2014; Nurprawitiningsih et al. 2015). 
Table 1.

Supporting parties and forms of participation in the management of inorganic waste in Karangmangu Village

\begin{tabular}{|c|c|c|}
\hline No & Supporting Parties & Forms of Participation \\
\hline 1 & Karangmangu Village & Providing garbage carts, garbage trucks, land for \\
\hline & Government & TPA \\
\hline 2 & Urban Poverty Program (P2KP) & Waste bank buildings \\
\hline 3 & UNSOED & $\begin{array}{l}\text { Socialization and handicraft competitions from } \\
\text { inorganic waste }\end{array}$ \\
\hline 4 & Poltekes & Organic and inorganic waste bins \\
\hline 5 & $\begin{array}{l}\text { Midwives of Karangmangu } \\
\text { Village }\end{array}$ & Socialization, briefing, and assistance \\
\hline 6 & $\begin{array}{l}\text { head of the Village Health } \\
\text { Forum (FKD) of Karangmangu } \\
\text { Village }\end{array}$ & $\begin{array}{l}\text { Socialization and invitation for a comparative study } \\
\text { to Yogyakarta }\end{array}$ \\
\hline 7 & $\begin{array}{l}\text { Final Disposal Site Manager } \\
\text { (TPA) controllers }\end{array}$ & $\begin{array}{l}\text { Transporting the waste and managing the TPA of } \\
\text { Karangmangu Village }\end{array}$ \\
\hline $\begin{array}{l}8 \\
9 \\
10\end{array}$ & $\begin{array}{l}\text { Waste bank controllers } \\
\text { Karangmangu Village Head } \\
\text { Health cadres of Karangmangu }\end{array}$ & $\begin{array}{l}\text { Managing the waste bank of Karangmangu Village } \\
\text { Monitoring management of inorganic waste } \\
\text { Providing socialization and empowerment for the }\end{array}$ \\
\hline 11 & $\begin{array}{l}\text { Village } \\
\text { PKK groups of Karangmanqu }\end{array}$ & $\begin{array}{l}\text { community to manage inorganic waste } \\
\text { Socialization }\end{array}$ \\
\hline & Village & \\
\hline 12 & $\begin{array}{l}\text { Non-Governmental } \\
\text { Organizations (LSM) }\end{array}$ & Health education \\
\hline
\end{tabular}

\section{Resources and supporting infrastructure for management of inorganic waste in Karangmangu Village}

In the in-depth interviews, all cadres argued that the existing resources had not been able to support the management of inorganic waste in the village. The community has not yet taken the initiative in managing inorganic waste and the community behavior patterns are difficult to change. This is mentioned in the following quote:

\footnotetext{
"Nothing. Mostly my own initiative hehehehe. The community is passive. There is a waste bank here, but they are lazy to deposit the waste. Actually, they know what I am doing there (pointing to the waste bank), but they are lazy because they only get five thousand a year (pointing to the residents of Karangmangu Village who have not joined the waste bank)" (YAT)

“...the mindset of people's behavior is quite difficult to change. They just want it to be simple. Human resources understand that waste must be managed, but sometimes the behavior has always been like that, so it's difficult to change. So, changes occur slowly" (LIL)
}

The resources that the cadres feel have not been able to support the management of inorganic waste in Karangmangu Village include first, human resources where some of the people of Karangmangu Village already aware of inorganic waste and its management but have not fully applied it on daily basis. Therefore, people have not separated organic and inorganic waste before throwing it into the trash bins. Some people also have not deposited inorganic waste into the waste bank so that the function of the waste bank has not been used optimally by the people of Karangmangu Village. In addition, the community also does not want to manage inorganic waste by making handicrafts because they think it is difficult and they cannot make them. Second, cadres argued that the management of inorganic waste techniques in Karangmangu Village is still lacking. This is because inorganic waste that is no longer used is still burned at the Final Disposal Site (TPA), causing air pollution around the TPA.

Resources are an essential factor in implementing a policy, including waste management. One of the obstacles experienced by the government in implementing a policy is the lack of community skills and abilities in implementing them (Wahyuni 2012). The importance of resources in inorganic waste management requires manpower and resources, particularly human resources (Libriyanti 2013). 
Regarding the supporting infrastructure, the cadres stated that the existing facilities and infrastructure did not support the management of inorganic waste in the village, as evidenced by their initiative and only assistance in the form of a waste bank building, carts, and trash bins. This is mentioned in the following statements:

\footnotetext{
"Not yet. I was asked by the village head regarding the need for waste management. But I said that I haven't needed anything. This is because of my initiative that is supported by my husband. Many of the parts of the building have leaks, so I want to fix them first (while showing the building next to her house which will later be used for the waste bank building). Indeed, he bought the scales (pointing to the husband)" (NAN)

"Perhaps what is needed is a waste bank, waste cart, and a village car. The village car is actually made to transport corpses because the cemetery in Baturraden is far away, Ms. However, the car will be washed clean after being used to transport waste" (YAN)
}

Based on the cadres' opinions, several facilities and infrastructure have not been able to support the management of inorganic waste in Karangmangu Village. Existing facilities and infrastructure include a building for a waste bank, waste carts, waste trucks, and Final Disposal Sites (TPA). Some of the cadres need a building for a waste bank as a cooperative or a container to accommodate handicraft products from inorganic waste, a sewing machine to help make the handicrafts, and separate organic and inorganic waste bins because so far the community has been separating waste and disposing of waste using former rice sacks called kandi.

Support for existing waste facilities in the form of a waste fleet and other equipment is included as the supporting factors in the implementation of the waste management performance program although the number is still categorized as minimal in waste services (Said \& Noor 2015).

\section{Inhibiting factors in the management of inorganic waste}

The inhibiting factors are the obstacles for cadres in managing inorganic waste in Karangmangu Village. They include the aspect hindering the management of inorganic waste in Karangmangu Village and the way to overcome the obstacles in the management of inorganic waste in Karangmangu Village. The results of the in-depth interviews with the cadres showed that there was no community willingness to make handicrafts from inorganic waste, lack of facilities and infrastructure (sewing machines, trash cans, and waste bank buildings), the difficulty of advancing the community, lack of public awareness, lack of patience in making handicrafts, marketing problems, inappropriate community behavior in managing inorganic waste, lacking human resources, and lack of a place to accommodate handicraft production. This is as presented in table 2 .

The cadres' statements regarding the obstacles in the management of inorganic waste is the same as those of the supporting informants of the head of the FKD and the village midwife that the aspects hindering the management of inorganic waste in Karangmangu Village are the lack of public awareness and the marketing of handicraft products which is only done through word of mouth. This is evidenced in the following quote, "The issue with cadres could be that no leader is truly patient. In addition, it is because of the lack of a monitor. Then, public awareness is also still lacking" (NAH). Besides, the obstacles including the lack of public awareness and product marketing through word of mouth are also conveyed by one of the informants as shown by the following statement, "For marketing, they only use word of mouth. They don't have a place like a shop or a storefront yet" (SAR).

The cadres' ways of overcoming the obstacles in the management of inorganic waste are almost the same as stated by the supporting informant of the TPA controller of Karangmangu Village, which is by always warning and providing socialization to the community as in the following quote, "Yes, just like that, Sis, at least the socialization continues to be implemented" (DAR). 
Table 2.

Inhibiting Factors and Strategies for Management of Inorganic Waste

\begin{tabular}{|c|c|}
\hline $\begin{array}{l}\text { Inhibiting factors for the } \\
\text { management of inorganic waste }\end{array}$ & Strategies to overcome the obstacles \\
\hline $\begin{array}{l}\text { 1. People don't want to make } \\
\text { crafts from inorganic waste }\end{array}$ & $\begin{array}{l}\text { 1. Overcome the waste bank problem by } \\
\text { themselves (buy the scale themselves) }\end{array}$ \\
\hline $\begin{array}{l}\text { 2. Lack of facilities and } \\
\text { infrastructure (sewing } \\
\text { machines, and waste bank }\end{array}$ & $\begin{array}{l}\text { 2. Train the community to make handicrafts } \\
\text { from inorganic waste (flowers, tissue boxes, } \\
\text { bags) }\end{array}$ \\
\hline buildings) & 3. Encouraging the public to deposit inorganic \\
\hline 3. The difficulty of advancing the & waste to the waste bank \\
\hline $\begin{array}{l}\text { community } \\
\text { 4. Lack of public awareness }\end{array}$ & $\begin{array}{l}\text { 4. Starting from oneself by separating plastic, } \\
\text { paper, cans, and inorganic waste }\end{array}$ \\
\hline $\begin{array}{l}\text { 5. Lack of patience of the } \\
\text { community in making } \\
\text { handicrafts }\end{array}$ & $\begin{array}{l}\text { 5. Held a handicraft competition made from } \\
\text { inorganic waste so that the community is } \\
\text { enthusiastic }\end{array}$ \\
\hline $\begin{array}{l}\text { 6. Inappropriate community } \\
\text { behavior in managing inorganic } \\
\text { waste }\end{array}$ & $\begin{array}{l}\text { 6. Provision of facilities and infrastructure } \\
\text { (waste bins, inorganic waste management } \\
\text { system) }\end{array}$ \\
\hline Lacking human resources & Community service \\
\hline Marketing problems & Providing a river cleaning program \\
\hline $\begin{array}{l}\text { Lack of a place to accommodate } \\
\text { handicraft production }\end{array}$ & $\begin{array}{l}\text { 9. The existence of a supporting system and } \\
\text { policy for the management of inorganic } \\
\text { waste } \\
\text { 10. Cooperate to manage inorganic waste } \\
\text { 11. Social sanctions (reprimand) will apply if } \\
\text { people are not managed the waste properly } \\
\text { 12. People tend to be independent } \\
\text { 13. Asking people who have sewing machines to } \\
\text { make handicrafts } \\
\text { 14. Selling handicraft products by word of mouth }\end{array}$ \\
\hline
\end{tabular}

Source: Processed Primary Data

The most essential thing in community-based waste management with the application of $3 \mathrm{R}$ is community participation. Therefore, cadres and people need to take an effective approach to give a big influence on the community to raise public awareness and community participation in waste management, particularly activities to reduce waste generation and sort waste at generation sources (Wahyuni 2013).

Socialization from cadres to the community aims to encourage the community to participate in managing inorganic waste. The activities of environmental cadres in encouraging their neighbors to maintain the quality of the environment around their respective homes include dealing with issues of cleanliness and waste recycling as well as providing knowledge and skills in processing waste to the community. It has accelerated the pace of waste management activities (Wahyono 2013).

Marketing is a significant part of the production process, including the production of handicrafts based on inorganic waste. Marketing strategy training is important for product makers so that the products can reach consumers. Therefore, they can generate profits. Marketing strategy training aims to make the product broadly accepted and recognized by the public and sell well in the market. The role of marketing is not only to deliver the product to consumers but also how to make the product or service able to provide satisfaction to customers by generating profits (Kartikawati 2014).

The transformation of values embodied in the pillars of sustainable development goals has also been felt in annual priority programs including on the social, environmental, economic, and legal, and governance development whose presence is seen continuing to be pursued (Irawan et al. 2021). In addition to increasing community involvement, innovation and creativity are required to solve 
environmental problems (Ruliana et al. 2019; Hamudy \& Mujaeni 2021). The involvement of social institutions, legitimacy, and participation of the government, the private sector, and the community, both individually and in groups, is significant in carrying out conservation activities to preserve natural resources. Furthermore, the linkage of economic activities must be included in conservation activities to improve the effectiveness of sustainable community conservation activities (Mohamad et al. 2012; Wang et al. 2018; Sudiasmo \& Muspita 2020; Ghazali et al. 2021). Its realization is by encouraging the development of independent and sustainable villages by having social, economic, and environmental resilience (Fatem 2011; Putri et al. 2020). It takes harmonious development of rural areas and industrial areas that are prone to conflict (Akbar et al. 2020).

\section{Conclusion}

The behavior of cadres in the management of inorganic waste includes managing waste banks, depositing inorganic waste to waste banks, making handicrafts, and mobilizing other cadres and the community in managing inorganic waste through socialization. Support for waste management activities comes from various sectors through the provision of facilities for the management of inorganic waste activities.

Inhibiting factors in the management of inorganic waste are the lack of community desire to make handicrafts from inorganic waste, lack of infrastructure (sewing machines and waste bank buildings), the difficulty of advancing the community, lack of public awareness, lack of patience in making handicrafts, lack of community behavior in managing inorganic waste, lack of human resources, marketing problems, and the lack of a place to accommodate handicraft production.

Strategies to overcome obstacles in the management of inorganic waste are overcoming the waste bank problem by themselves (buying the scale themselves), training people to make handicrafts from inorganic waste (flowers, tissue boxes, bags), encouraging people to deposit inorganic waste to the waste bank, starting from oneself by separating plastic, paper, cans, and inorganic waste, hold a handicraft competition from inorganic waste so that people are enthusiastic, provision of facilities and infrastructure (trash cans, inorganic waste management system), community service, river cleaning programs, system and policies that support inorganic waste management, cooperation in managing inorganic waste, apply social sanctions (reprimand) if people are not managing waste properly, people tend to be independent, asking people who have a sewing machine to make handicrafts, and sell handicraft products by word of mouth.

\section{References}

Akbar AAS, Pratiwi OC, Nurprojo IS, \& Firdaus S (2020) Mencari ruang penghidupan bersama antara kawasan perdesaan dan kawasan industri. Masyarakat, Kebudayaan dan Politik 33 (1):87-100. https://doi.org/10.20473/mkp.V33I12020.87-100.

Beni MT, Arjana IGB, \& Ramang R (2014) Pengaruh faktor-faktor sosial-ekonomi terhadap perilaku pengelolaan sampah domestik di Nusa Tenggara Timur. Jurnal Ilmu Lingkungan 12 (2):105117. https://doi.org/10.14710/jil.12.2.105-117.

Budiasih KS (2010) Pemilahan sampah sebagai upaya pengelolaan sampah yang baik. Thesis, Universitas Negeri Yogyakarta, Yogyakarta.

Chen L \& Gao M (2020) A new learning interaction rule for municipal household waste classification behavior based on multi-agent-based simulation. Journal of Cleaner Production 271: 122654. https://doi.org/10.1016/j.jclepro.2020.122654.

Chotimah DC \& Sholeh M (2015) Hubungan tingkat pendidikan ibu rumah tangga dengan praktik pemilahan sampah di Kelurahan Sekaran Kecamatan Gunungpati Kota Semarang. Jurnal Edu Geograhy 3 (7):30-36.

Christiawan PI \& Citra IPA (2016) Studi timbulan dan komposisi sampah perkotaan di Kelurahan Banyuning. Jurnal Media Komunikasi Geografi 17 (2):13-24. http://dx.doi.org/10.23887/mkg. v17i2.9024. 
Darwati S \& Anggraini F (2012) Peran komunitas dalam pengelolaan sampah berbasis pola pilah kumpul olah terhadap reduksi sampah kota. Jurnal pemukiman 7 (1): 24-32.

Dwiyanto BM (2011) Model peningkatan partisipasi masyarakat dan penguatan sinergi dalam pengelolaan sampah perkotaan. Jurnal Ekonomi Pembangunan 12 (2):239-256. https://doi. org/10.23917/jep.v12i2.196.

Fatem A (2011) Policies in village development: Learning from community empowerment and participation in Jayapura. International Journal of Administrative Science \& Organization 18 (2):108-121.

Ferdiansyah ME \& Arsiyah A (2014) Peran pemerintah dan kader masyarakat dalam pemberdayaan masyarakat untuk pengolahan sampah. JKMP 2 (2):103-220. https://doi.org/10.21070/jkmp. v2i 2.438 .

Fitriana A \& Oedojo S (2013) Perilaku ibu rumah tangga dalam pengelolaan sampah di Desa Bluru Kidul RW 11 Kecamatan Sidoarjo. Jurnal Promkes 1 (2):132-137.

Ghazali A, Thakraatmadja JH, Sunarti, \& Pratiwi EYD (2021) Resident-based learning model for sustainable resident participation in municipal solid waste management program. Global Journal of Environmental Science and Management 7 (4):599-624. https://doi.org/10.22034/ gjesm.2021.04.08.

Hamudy MIA \& Mujaeni M (2021) The creativity of waste management in Payakumbuh City, West Sumatera. Masyarakat, Kebudayaan dan Politik 34 (1):58-71. https://doi.org/10.20473/mkp. V34I12021.58-71.

Irawan B, Akbar P, Purnomo EP, \& Nurmandi A (2021) Development planning to accelerate Sustainable Development Goals (SDGs) in Mahakam Ulu District as a new autonomous region. Masyarakat, Kebudayaan dan Politik 34 (2):184-195. https://doi.org/10.20473/mkp.V34I22021.184-195.

Jimung M (2008) Analisis hubungan antara faktor sanitasi air bersih, pengetahuan dan perilaku ibu terhadap penyebab penyakit diare pada anak balita di wilayah kerja Rumah Sakit Fatima Kota Parepare. Jurnal MKM 7 (1):28-36.

Kabupaten Banyumas (2010) Buku Putih Sanitasi Kabupaten Banyumas. Banyumas: Pemkab Banyumas.

Kartikawati MTD (2014) Perencanaan program peningkatan pemasaran hasil produksi pertanian/ perkebunan di Kota Batu. Thesis, Universitas Brawijaya, Malang.

Libriyanti R (2013) Pengelolaan sampah berbasis masyarakat. Thesis, Universitas Negeri Semarang, Semarang.

Lissah SY, Ayanore MA, Krugu JK, Aberese-Ako M, \& Ruiter RAC (2021) Managing urban solid waste in Ghana: Perspectives and experiences of municipal waste company managers and supervisors in an urban municipality. PLoS ONE 16 (3):e0248392. https://doi.org/10.1371/ journal.pone.0248392.

Liu X, Wang Z, Li W, Li G, \& Zhang Y (2019) Mechanisms of public education influencing waste classification willingness of urban residents. Resources, Conservation and Recycling 149: 381390. https://doi.org/10.1016/j.resconrec.2019.06.001.

Meng X, Tan X, Wang Y, Wen Z, Tao Y, \& Qian Y (2019) Investigation on decision-making mechanism of residents' household solid waste classification and recycling behaviors. Resources, Conservation and Recycling 140: 224-234. https://doi.org/10.1016/j.resconrec.2018.09.021.

Mohamad F, Sutra DC, \& Kusnawati E (2012) Pemberdayaan masyarakat dalam pengelolaan sampah di Dukuh Mrican Sleman Yogyakarta. Jurnal Health \& Sport 5 (30):695-706.

Naditya R, Suryono A, \& Mochamad R (2012) Implementasi Peraturan Daerah Kota Malang Nomor 10 Tahun 2010 Tentang Pengelolaan Sampah (suatu studi kasus di Dinas Kebersihan dan Pertamanan (DKP) dalam pelaksanaan program Bank Sampah Malang (BSM) di Kelurahan Sukun Kota Malang). Jurnal Administrasi Publik (JAP) 1 (6):1086-1095.

Notoatmodjo S (2010) Ilmu Perilaku Kesehatan. PT. Rineka Cipta: Jakarta.

Nurkomalasari D (2014) Pengembangan model pengelolaan sampah rumah tangga berbasis masyarakat di RW 08 Merbabu Asih Kota Cirebon. Journal of Educational Social Studies 3 (2):1-5.

Nurprawitiningsih L, Suhandini P, \& Bonawati E (2015) Pengelolaan sampah rumah tangga berbasis masyarakat di Kelurahan Sekaran Kecamatan Gunungpati Kota Semarang. Journal of Educational Social Studies 4 (1):1-6. https://doi.org/10.15294/JESS.V4I1.6862. 
Pierini VI, Mazzeo N, Cazenave M, \& Semmartin M (2021) Waste generation and pro-environmental behaviors at household level: A citizen science study in Buenos Aires (Argentina). Resources, Conservation and Recycling 170: 105560. https://doi.org/10.1016/j.resconrec.2021.105560.

Putri CT, Wardiyanto B, \& Suaedi F (2020) Evaluasi kebijakan dana desa melalui desa wisata agro guna menciptakan pembangunan lokal berkelanjutan. Masyarakat, Kebudayaan dan Politik 33 (2):174-183. https://doi.org/10.20473/mkp.V33I22020.174-183.

Rachman I, Soesanto QMB, Khair H, \& Matsumoto T (2020) Participation of leaders and community in solid waste management in Indonesia to reduce landfill waste load. Journal of Community Based Environmental Engineering and Management 4 (2):75-84. http://dx.doi.org/10.23969/ jcbeem.v4i2.3348.

Rahman A (2013) Perilaku masyarakat dalam pengelolaan sampah rumah tangga (studi kasus di Kelurahan Pasar Sarolangun). Jurnal Bina Praja 5 (4):215-220.

Ruliana V, Soemantojo RW, \& Asteria D (2019) Assessing a community-based waste separation program through examination of correlations between participation, information exposure, environmental knowledge, and environmental attitude. ASEAN Journal of Community Engagement 3 (1):1-27. https://doi.org/10.7454/ajce.v3i1.120.

Said LOA \& Noor M (2015) Implementasi kebijakan pengelolaan persampahan kota Baubau. Jurnal Ilmu Sosial dan Ilmu Politik 4 (1):67-80.

Sudiasmo F \& Muspita CN (2020) Local wisdom in environment conservation: A study on a conservation and energy self-sufficient village Kearifan lokal dalam konservasi lingkungan: Studi pada desa konservasi dan mandiri energi. Masyarakat, Kebudayaan dan Politik 33 (4):405-412. https://doi. org/10.20473/mkp.V33I42020.405-412.

Susilowati S \& Herdiansyah H (2019) Application of waste bank use in reducing household waste in suburban area. Journal of Physics: Conference Series 1381: 012050. https://doi.org/10.1088/17426596/1381/1/012050.

Tampubolon DH, Rauf, A \& Sitanggang G (2014) Pengujian media tanam kompos dan residu sampah rumah tangga terhadap basa tukar, Ktk, $\mathrm{Kb}$ dan produksi tanaman sawi (Brassica Juncea L. Czern) di lahan pekarangan Kec. Sunggal. Jurnal Online Agroekoteknologi 2 (3):1080-1087. https://doi.org/10.32734/jaet.v2i3.7465.

Wahyono S, Sahwan FL, \& Feddy S (2013) Pengelolaan sampah berbasis masyarakat di Rawasari, Kelurahan Cempaka Putih Timur, Jakarta Pusat. Jurnal Teknik Lingkungan 13 (1):75-84.

Wahyuni A (2012) Peran Dinas Kebersihan dan Pertamanan Kota Samarinda dalam pengelolaan sampah di Kota Samarinda. Jurnal Ilmu Pemerintahan 1 (2):751-760.

Wang Z, Guo D, Wang X, Zhang B, \& Wang B (2018) How does information publicity influence residents' behaviour intentions around e-waste recycling? Resources, Conservation and Recycling 133: 1-9. https://doi.org/10.1016/j.resconrec.2018.01.014. 